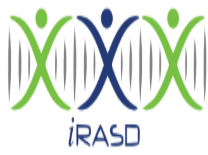

iRASD Journal of Management

Volume 3, Number 3, 2021, Pages 339 - 359

Journal Homepage:

https://journals.internationalrasd.org/index.php/jom

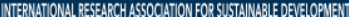

\title{
Trends of Power Devolution in South Asia: A Comparative Appraisal of Pakistan's Local Government System under the Civil-Military Regimes
}

\author{
Asifa Jahangir ${ }^{1}$, Rubeel Zain ${ }^{2}$, Soulat Dilkusha ${ }^{3}$ \\ ${ }^{1}$ Centre for South Asian Studies, University of the Punjab, Lahore, Pakistan. Email: asifajahangir2327@gmail.com \\ ${ }^{2}$ Centre for South Asian Studies, University of the Punjab, Lahore, Pakistan. \\ ${ }^{3}$ Department of International Relations, Lahore College for Women University, Lahore, Pakistan.
}

\section{ARTICLE INFO}

\section{Article History:}

Received:

Revised:

Accepted:

November 23, 2021

December 29, 2021

Available Online: Dece

\section{Keywords:}

Power Devolution

Local Government System

South Asia

Pakistan

Military Regime

Civilian Government

\section{ABSTRACT}

In the South Asian countries, the trends of power sharing, decentralization and power evolution have not only always remained a pertinent debate for the consolidation of democracy and good governance, but also static political systems due to their multiethnic realities, multilingual differences, multicultural diversification, and their authoritarian orientation in the respective countries. Historically, the transfer of power through the local system of government (LGS) was seen as an important tool to accelerate the transition to representative democracy on the subcontinent. However, it was largely aimed at creating a new political class that would support colonial rule and meet the political demands of the local population for power sharing within the boundaries of the colonial government structure. Due to their embedded interests, the colonial legacies in South Asian states offered non-representative state institutions such as the military enough space to influence the transformation process of democracy. The paper has two main objectives: (1) to explore the concepts of power devolution and their associative nomenclature; (2) to analysis of the political and administrative dimensions of decentralization to underpin the structure of decentralization in South Asia in general and Pakistan in particular. The results of the study are that the lack of the weakest local government system in the South Asian region in general, and in Pakistan in particular, is due to the colonial legacy of an ongoing controlled political mindset in the form of bureaucracy, frequent military coups, a lack of political will to develop a welfare state in Pakistan. It uses the qualitative research methods of phenomenology and correlation, which sheds light on the meaning of relative terms often used to explain delegation of authority for political and administrative purposes.

(C) 2021 The Authors, Published by iRASD. This is an Open Access article under the Creative Common Attribution Non-Commercial 4.0

Corresponding Author's Email: asifajahangir2327@gmail.com

\section{Introduction}

The concept of power distribution and effective governance can be traced back to Islamic history. Hazrat Umar Farooq Razi Allah Tala Anhu was the first person to delegate powers to subordinate political structures for better governance, as the Islamic Empire expanded at a rapid pace during his rule (Imran, 2015). The same culture was practiced during Muslim rule in the subcontinent, and powers were transferred to the local level as more people became involved in the political administration structure. A kind of local democracy in the form of village panchayats has been practiced in the region of the subcontinent for many centuries. In different societies in the South Asian region, however, 
its nature was little different. Panchayats (council of five) usually exercised legal, administrative, and sometimes developmental functions within the framework of the concept of self-help (Cheema, 2005). Its members were nominated from among the famous and respected people of the village.

Later the entire South Asian region came under British influence. It is often claimed that the local government institutions did not have deep roots in India because the British were unwilling to disrupt the traditional social fabric that existed in the villages. The British introduced the institution of local government as a superstructure, in which a village existed, with the main functions of maintaining law and order, administering justice, and performing other social functions. In addition, district officials dominated these institutions and often sought the cooperation of landowners or tribal leaders to maintain law and order and to collect income to fight for independence rather than transform traditional society (Said 2014). In simple terms, the UK government has made efforts from time to time to promote local institutions through reforms, but essentially under the control of the provincial government through district officials. The design and structure of today's local governments in South Asia were developed along the same lines that the British had anchored in their colonized areas. Even so, the British have never tried to disrupt the basic structure of the panchayats or any of their other forms.

Methodologically, primary, and secondary data were used in this article. About the primary data, the municipal laws of 2001, 2010, 2013 and 2019 were used. The qualitative approach uses phenomenology and correlation research techniques that shed light on the meaning of relative terms often used to explain delegation of authority for political and administrative purposes. After a brief examination of traces of the devolution of power/local democracy, this article deals with the three most important aspects of the topic: Understanding of common terms and concepts of decentralization, decentralization tendencies in South Asia and finally a comparative appraisal of the reforms within the framework of the local government system in Pakistan from non-representative military regimes (Generals Zia-ul-Haq, Ayub Khan and Musharraf) and non-participatory, unresponsive civil governments before the current governments.

The paper has two main objectives: (1) to examine the concepts of power distribution and their associative nomenclature; (2) to analyze the political and administrative dimensions of decentralization to underpin the structure of decentralization in South Asia in general and Pakistan in particular. This goal of the study has two subgoals; (i) With respect to Pakistan, the paper examines the past intentions and efforts of military regimes and civilian elected governments in the context of their political interests, their respective decentralization philosophies, and the directions of the decentralization process. (ii) To compare the status and performance of LSGs under different civil governments in Pakistan.

\section{Concepts and Terms of Devolution}

Governance issues are dealt with in each country by different levels of government, which are mainly central and unitary (province). Power distribution is usually referred to in political administration as the transfer of power from the center to local government or communities promoted as a means of facilitating good governance. In the words of Larson, the concept of decentralization supports the transfer of rights and assets to manage resources from the center to local government or institutions inside and outside government (Larson, 2002).

Rural areas are initiated by many countries on a third level, in which the powers are delegated to the local population of the affected areas. This goal is to make government services more efficient by bringing governance mechanisms closer to people. So, people can solve their problems with the help of their elected representatives. This trend of disruptive power from the center to the local authorities is made by the constitution of each state. The degree of autonomy granted to local governments or bodies is set out in the constitution, which essentially requires the type of government in each country. These bodies give citizens the opportunity to participate in the affairs of the country, to administer their territories and to solve their own problems with material and immaterial means. In this 
way, the municipalities fulfill their responsibilities within their borders and enable the citizens to change their conditions with their abilities.

Some federal states advocate the transfer of greater and others less autonomy to the municipalities. In this system there are three levels of government: central, intermediate (provinces) and local. Even some countries based on a unitary system prefer to maintain a controlled system of power, and the central government can only make decisions about the transfer of power to local units at any one time.

Whereas in the federal system both the center and the provinces have constitutionally protected autonomy, and the powers are clearly defined (Tate, 2014). In other South Asian countries, the system of government includes, in addition to the levels mentioned above, another bureaucratic level, which still stands before the provinces and controls the entire system with an iron hand, just as the entire political system was once created by the British.

In the process of governance in any democratic country, the system of local government is a central source for connecting the machinery of government with the masses to provide good services. It stimulates socio-political mobilization in various productive segments of society and promotes leadership at the local level. There is a conceptual link between governance and local government. Both are closely related to policy-making processes in a wide range of domains and administrative systems over the exercise of power through the management of a country's socio-economic resources for development (The World Bank, April 1998: 3). In both systems, the role of statutory institutions is very important, and their functions have been recognized by the Constitution. Constitutional principles and the democratically established legal framework oblige central government to delegate administrative power, public resources, and responsibilities (Johnson, 2003: 4) to local and sub-local governments, which are either created or strengthened (Blair, 2000: 3). In addition, local government institutions create responsiveness by integrating peripheral parts of society into a political system. Conceptually, there are few analogous terms that are often used to explain transfer of power: decentralization, decentralization, and delegation.

\subsection{Decentralization}

Is a political process in which responsibilities for politics, administration and finance are transferred to subordinate units (ministries or agencies) of the centrally controlled government (Crook and Manor, 1998: 67; Rondinelli et al., 1989; Meenakshisundaram, 1999: 55). In other words, in decentralization, central government shares responsibility with large and centrally administered bureaucracies (Johnson, 2001: 3). Furthermore, the World Bank has defined it as the division of the political, administrative, and fiscal responsibilities of the central government among the intermediate and local governments. It works out two dimensions of successful decentralization. First, political decentralization refers to the power of decision making, where necessary changes are usually made in constitutions and legal frameworks. Second, the decentralization of finance and administration are essential to the implementation of decisions, the proper allocation and equal distribution of financial and human resources, ensuring the efficient delivery of services and the development of a systematic structure based on accountability and transparency (Decentralization in South Asia the World Bank).

\subsection{Decentralization}

is a political process in which subnational government units are either created or strengthened by giving them powers for political, administrative, and fiscal tasks (Blair, 2000; Crook and Manor, 1998: 67; Rondinelli et al., 1989).

\subsection{Delegation}

Is a political process in which responsibilities are transferred to organizations that lie outside the regular bureaucratic structure and are only indirectly controlled by the central government (Johnson, 2001 and 2003: 3 \& 4; Meenakshisundaram, 1999: 55). 


\section{Trends of devolution in South Asia}

Several South Asian countries in our way or another have moved ahead with political decentralization. Table 1 shows an overview of devolution of power in the South Asian countries regarding Constitutional distribution of power and underlying reason of devolution, along with constitutional amendment and its objective.

\section{Table 1}

An Overview of Devolution of Power in the South Asian Countries

\begin{tabular}{|c|c|c|}
\hline Country & $\begin{array}{l}\text { Constitutional } \\
\text { organization of a } \\
\text { state/Constitutional } \\
\text { distribution } \\
\text { Power }\end{array}$ & $\begin{array}{l}\text { Possible reason } \\
\text { underlying } \\
\text { decentralization }\end{array}$ \\
\hline India & $\begin{array}{l}\text { State with strong } \\
\text { state governments } \\
\text { and a Panchayat } \\
\text { system }\end{array}$ & $\begin{array}{l}\text { Alternative to the } \\
\text { authoritarian } \\
\text { bureaucracy from } \\
\text { the colonial era. }\end{array}$ \\
\hline Pakistan & Big-bang approach ${ }^{1}$ & $\begin{array}{l}\text { To gain } \\
\text { legitimacy from } \\
\text { lower levels for } \\
\text { maintaining top- } \\
\text { down } \\
\text { government and } \\
\text { the system they } \\
\text { run. }\end{array}$ \\
\hline Nepal & $\begin{array}{l}\text { Representative } \\
\text { Monarchy }\end{array}$ & $\begin{array}{l}\text { Previously: donor } \\
\text { pressure; Now: } \\
\text { Resolve conflicts } \\
\text { by reallocating } \\
\text { authority and } \\
\text { improving } \\
\text { service. }\end{array}$ \\
\hline
\end{tabular}

state governments

\section{Constitutional \\ Amendments \\ underpinning \\ for}

culture

decentralization and

issued date

73rd and 74th

7rd and 74 th

However, while Generals Ayub Khan (1958-1969), Zia ul Musharraf (1999-

2008) initiated influential

decentralization, the final general's decentralization plan in 2000-2001 is seen as a far-reaching strategy that central powers to new local governments are aimed at a transfer. The Local SelfGovernment Act of 1999 defined three types of local government and gave them some revenue and expenditure powers. Haq (1979-1988) and

\section{Objective}

States must hold regular elections and allow funds and functions to be transferred to the lowest levels of government in urban and rural (local) areas.

The aim is to involve youth and marginalized sections of society in the country's political system so that they can contribute to the development of a system based on strong accountability between local voters and new politicians. In December 2008, the Prime Minister set up a committee to review the 2001 Local Government Ordinance. Some argue that this is an attempt to strengthen the local government system. Others argue that the government's intent may be different.

Nepal is currently in a delicate transition from the monarchy and should approach the model of a federal state. In this context, the roles of the different levels of government, the number of levels and the nature of the financial flows are discussed and discussed. The political environment remains fragile, leading to uncertainty about the future of interstate financial relations in Nepal. Nepal is rewriting its constitution and redefining its intergovernmental structure from a unitary state to a federal state. This will determine the future of the decentralization strategy

An Articles 59 and 60 have created a framework for local authorities.

Bangladesh has been a parliamentary democracy since a constitutional amendment in 1991. After the recent elections in December 2008, efforts to promote democracy and fight corruption should remain high on the agenda of the government of

\footnotetext{
${ }^{1}$ Big bang approach is basically used for "instant changeover, when everybody associated with the new system moves to the fully functioning new system on a given date" (Eason, 1988).
} 
Bhutan Monarchy

Sri Lanka Unitary State
To counter the emergence of an oligarchy as the country opens up

Create public sector jobs in a country in conflict
Bangladesh. It is expected that decentralization will be one of the pillars to achieve these goals. the 9th Five-year Plan (2002/03-2006/07) and 10th Five-year Plan (2008/09â^'2012/13)

The constitutional amendment of 1987 called for comprehensive decentralization reform in the public sector and in service delivery.
Afghanistan
There is currently no strong preference for substantial political decentralization to sub-national levels.
Focus on the needs of the gewogs (rural communities) and dzongkhags (districts). The transfer of resources and decisionmaking authority to the local level is a central aim of the plans.

The reforms are intended to be part of the peace strategy, which addresses issues of ethnicity and local autonomy in the context of the civil war. Improved service delivery is an implicit goal. Local government is the third tier under the supervision of the newly created provincial councils. Despite the change, however, the government structure remains centralized; almost all provincial activities are tightly controlled by the center and the local authorities have limited tax and administrative powers.

The constitution refers to the maintenance of the principles of centralism. Similarly, the current political establishment subscribes to the current, de jure, centralized intergovernmental structure. Safety concerns will remain a major concern for years to come. The 2009 presidential and 2010 parliamentary elections will have a major impact on future political directions, including relations between the Center and subnational governments.

Source: The authors have drawn the table by using different sources.

\section{Comparative Appraisal of Reforms in Local Government System Made by Different Regimes and Governments in Pakistan \\ 4.1. Background}

This part of the study sought to understand how the Pakistani political system is shaped and how the concept of decentralization finds its support. It also compares local government reforms in various major eras to understand how fair decentralization was in our political history in 1959, the second plan was the establishment of local bodies in 1979, and the third was the decentralization of power in 2001. All were introduced by the military chiefs of the states, General Ayub Khan, General Zia-ul-Haq and General Pervaiz Musharraf, respectively.

After independence in 1947 there was no machinery to put administration in charge. There were parishes and union boards, but these were isolated from the district administration and not accountable to the people. It is believed that without the spirit of local bodies or institutions, a nation cannot have a spirit of freedom. In modern states, great importance is attached to the LGS to achieve the true spirit of democratic values, which means that the administration of the local areas is directed by their elected representatives. It is for this reason that local governments are referred to as elementary schools of democracy.

So, in 1947 Pakistan inherited this system of local government from British efforts to promote local institutions through reforms, laws and commissions. After independence, the policy of the government and the manifesto of the Muslims was that local bodies should be given full autonomy. However, during the first decade after its existence, Pakistan faced administrative change and political instability; the question of an adequate system of 
government has therefore always been in the spotlight (Mussarat 2011: 123). In this regard, the local system of government was underestimated and largely neglected until the Basic Democracies Order was promulgated in 1959, when Pakistan was initially faced with the problem of power-sharing between the center and the provinces.

One of the interesting facts about local governments in Pakistan was that they only thrived under military regimes, be it in the Ayub Khan, Zia-ul-Haq or Musharraf era. Many believe that the military leadership tried to plan, promote, and institutionalize local government institutions to gain political legitimacy. Against this background, this study presents a detailed historical analysis of the decentralization and decentralization of power reforms in different epochs in terms of content, process, and implementation from the political history of Pakistan. At this point it is appropriate to mention that it is in Pakistan according to the constitution There were three levels of government from 1973 (see Figure 1).

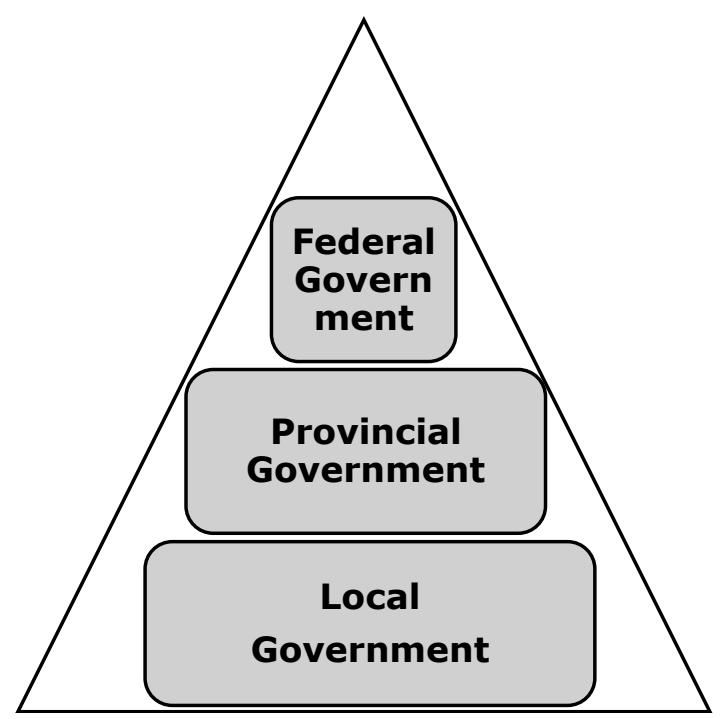

Figure 1: Tiers of Government in Pakistan as per the 1973 Constitution

Sources: the figure is made by the authors.

\subsection{The Ayub's Regime: decentralization and Politics of Legitimacy}

New local administrative units have been introduced across the country to manage local affairs through detailed laws under the Democracy Ordinance 1959 and the Local Government Ordinance 1960, which originally consisted of a system of five interconnected levels (see Figure 2). The lower tier members were elected on an adult suffrage basis, which means people were able to vote for men they knew directly for the ward councils. Some high-ranking members were official members nominated by the government, and some members were indirectly elected by directly elected lower-ranking members (Buneri, 2018: 6).

Under General Ayubs' regime, important steps were taken towards local government in the form of A Basic System of Democracy, which was an entirely new introduction to Pakistan's political system. Grassroots democracy was conceived in Pakistan with the aim of a limited democracy, the development of the political culture and the raising of awareness at the grassroots level. It is very similar to Basic English in that it was developed to allow foreigners with limited vocabulary to communicate in English.

The in-depth analysis shows that the system of local government within the framework of grassroots democracy has certain important objectives: (1) to strengthen the role of rural political participation to create rural leadership and to limit the role of urban political presentations. In this way, a shift of political participation from the city to the rural area and a promotion of common endeavors in the people as well as an understanding of the perception of responsibility were created. In this way the system would gradually work up from the bottom. This system would be free from political pressures that would counter the involvement of the bureaucracy and minimize the role of traditional political parties. (2) 
To centralize and strengthen the political power of the president which established a strong presidential system of government (Ziring, 1977: 249-256).

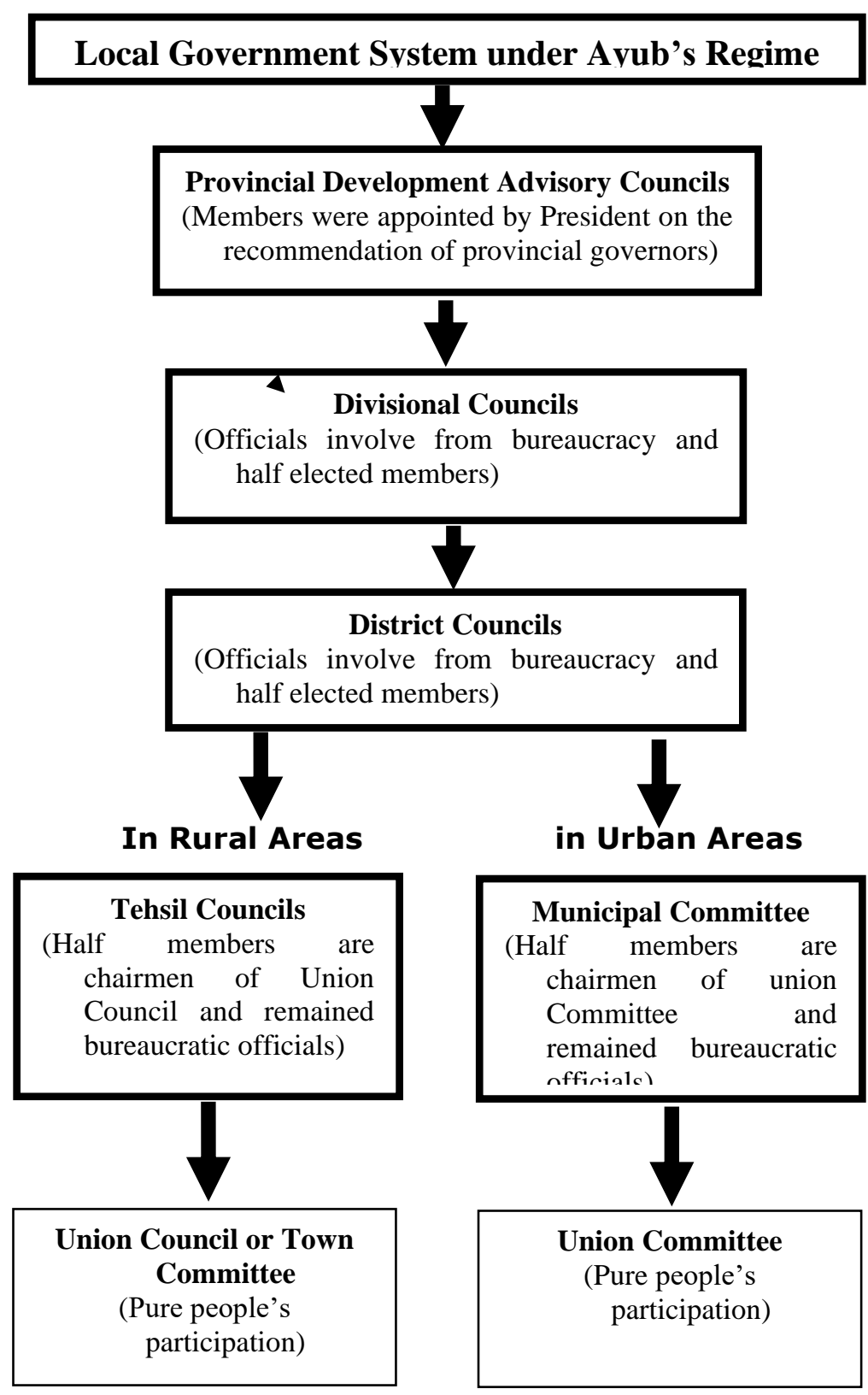

Figure 2: Structure of Basic Democracy System (BDS)

Source: the figure is drawn by the authors.

The main administrative unit of grassroots democracy in rural areas was the Union Council and for urban areas there are Union committees. Each union council that covers a group of villages often consists of fifteen thousand people. An elected member of the Union Council was represented by between 1,000 and 1,500 people. Members were elected based on adult suffrage to be able to interpret the feelings of the people in the council (Ahmed, 1970, 188-191). The union council covers a wide range of community development and economic activities, including human development such as promoting village industries, forestry, and ranching, adopted measures to increase food production, maintain water supplies and improve public roads and roads coordinate the promotion of health and education as well as land law and order maintenance with other departments.

The next stage was the Tehsiler Councils, and these bodies provided a forum for discussion of common problems and had to coordinate the activities of the union councils and district councils. Above that were district councilors who were also responsible for compulsory and elective functions; and had to fulfill all the mandatory functions as a union council in villages, but to carry out these duties, smaller union councils were grouped into 
municipal committees for divisions and passed it on to the district councils to make suggestions and put them into practice (Khan, 2009: 125-126).

\subsection{Critical Analysis}

The following points summarize the critical analysis of the system.

- $\quad$ The power of control lay within the bureaucracy. This means that this system has done little to free the citizen from the control of the bureaucracy. Since officials were responsible for selecting candidates, they increased administrative control. Their dominance and influence remained at the Tehsil, district, and division levels as deputy commissioners were appointed to higher-level presidents of local bodies.

- The government used the bureaucratic control of the center to restrict political competition at the local level. This managed democracy system enabled the bureaucrats to shut down council procedures related to any work, repeal their resolutions and bills, suspend all laws passed by local bodies, and even suspend elected councilors.

- $\quad$ The bureaucracy was believed to have been abolished, but it has been strengthened more. The power of the big industrialists and big landowners was unchallenged, which was the main hurdle in mobilizing the rural population around the institution of national integration. This controlled structure did not bode well for the common people of Pakistan.

- It is believed that the Union Councils were given priority, but the actual situation was completely different, e.g., Union council and committee chairmen gave no right to initiate development plans, make decisions, and were dependent on financial matters. It does not conform to the concept of autonomy that is the cornerstone of local government (Chiragh, 2004: 149).

- In addition, the provincial autonomy was restricted by the appointment of governors who were subordinate to the center. And the institutionalization of the political system did not take place, and no political culture was developed.

- In the 1962 Constitution, the most important and controversial function of the grassroots democracy scheme was to empower members of the lowest ranks to elect the president and members of provincial and national assemblies. In this way, this scheme prevented the locals from electing their representatives. It is critical that it was only created to support the dictatorship with the help of the bureaucracy.

- This system aimed to centralize and strengthen political power in the office of president, rather than decentralizing and decentralizing authority at the grassroots level. It helped establish a strong presidential system of government, but the system did not strengthen the political system and restricted political competition at the local level. Ultimately, the regime's political power should be institutionalized where the president achieves security and stability.

The Basic Democracy System was finally abolished in 1969, but even then, it is fair to say that it is the first step in the decentralization of power from the center to the locals. As Ashford notes, the decorative organization of councils organized by the Pakistani military bureaucratic oligarchy is certainly the most motivated of the three local reform systems (D.E. Ashford, 1967: 116).

\section{Decentralization Efforts in the Government of Zulfiqar Ali Bhutto}

As Prime Minister, Zulfiqar Ali Bhutto enjoyed the support of the country's political parties and drafted the 1973 constitution, which ushered in a new era of political stability. He announced the concept of People's Local Government. He then introduced local government laws in 1972 and 1975 that abolished direct representation of the bureaucracy in local government. Indeed, it was stated that all members for all levels of local government should be directly elected through adult suffrage (see Figure 3 ). This was a significant change from Ayub's Basic Democracy. But this popular measure was not implemented in its place of managing local affairs. He chose to use local bureaucrats rather than revitalizing local governments. In this new order, institutions of local government were created on their own account to maintain law and order. It had no political ties and represented minorities, women, farmers, and workers on the local council. Rather, new laws in local government introduced some useful reforms, but since local elections were never 
held under the new laws, the reforms were not implemented. The country had no local administrative system between 1971 and 1979 (Buneri, 2018).

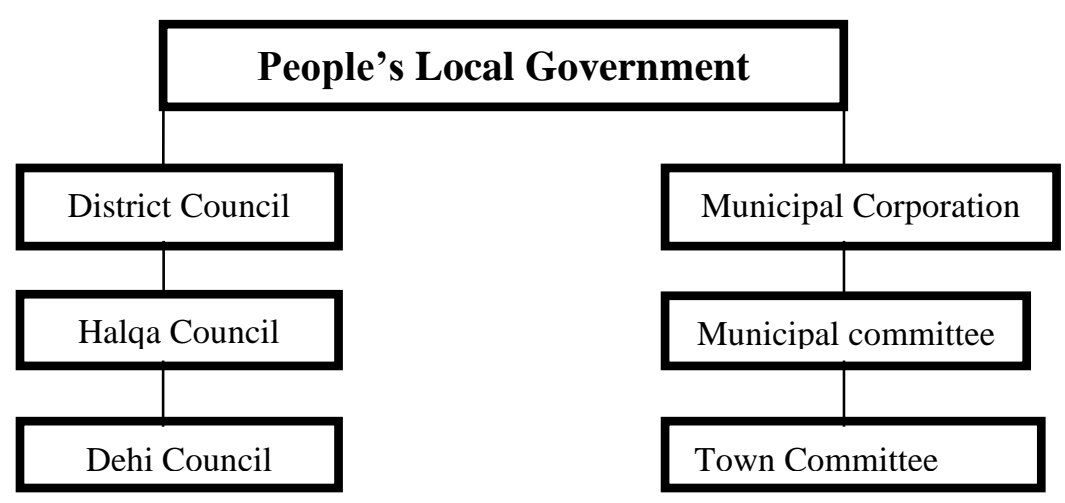

Figure 3: Structure of People's local Government System

Source: The figure is drawn by the authors.

In 1977, however, general elections were held, and Bhutto's party won by securing majority seats in the National Assembly. But the defeated political parties made serious allegations of election fraud against the government. As a result, Bhutto was removed by the military coup due to a deep constitutional crisis, ongoing ongoing agitation, and the failure of political parties to reach an amicable settlement. In 1977 General Muhammad Ziaul-Haq took over the government and promised to hold parliamentary elections within 90 days (Rabbani, 2006: 167). The dream of Bhutto's People's Local Government System ended with the decline of his time.

\section{Devolution of Power Reforms in General Zia-ul-Haq's Regime and the Post-Zia's Regime}

General Zia-ul-Haq opted for grass-roots democracy to gain political legitimacy. He declared the revitalization of local government under the Local Government Ordinance (LGO) of 1979. Under this policy, three local elections were held in 1979, 1983 and 1985 respectively. New local government laws have been drawn up for each province, with slight variations to reflect local circumstances. Zia wanted to create an institutional approach to implementing democratic practices. Therefore, it was important to him to first hold the local elections (on a non-party basis) in all provinces in 1979 and 1980 within 90 days of Zia's assumption of government (Mussarat, 2011: 131).

Elections to all local councils in rural and urban areas since adult suffrage were held for the first time and local government institutions were re-established to hold free and fair elections. As part of the LGO, a two-tier system for rural and a four-tier system for urban local government have been set up in each province (see Figure 3 ). The council members elected the chairman and vice chairman among themselves. Seats were reserved for women, non-Muslims, and minorities (Siddiqui, 1992: 108).

\subsection{Criticism}

Zia implemented the LGOs without elected bodies receiving constitutional protection. In addition, local governments received little financial power and mostly had to rely on federal and state grants, with the city council having high revenue and revenue, and rural and semi-urban areas relying on provincial administrative levels for financial support. In the Zias regime, however, Punjab was exempt from the local government structure (LG) and there were only Tehsil councils to coordinate with the rural government. Democratic decentralization at the local level found no roots despite several attempts by military rulers. The system known as the local body or local government system was not actually introduced; In fact, it was part of political culture in democratic societies. 


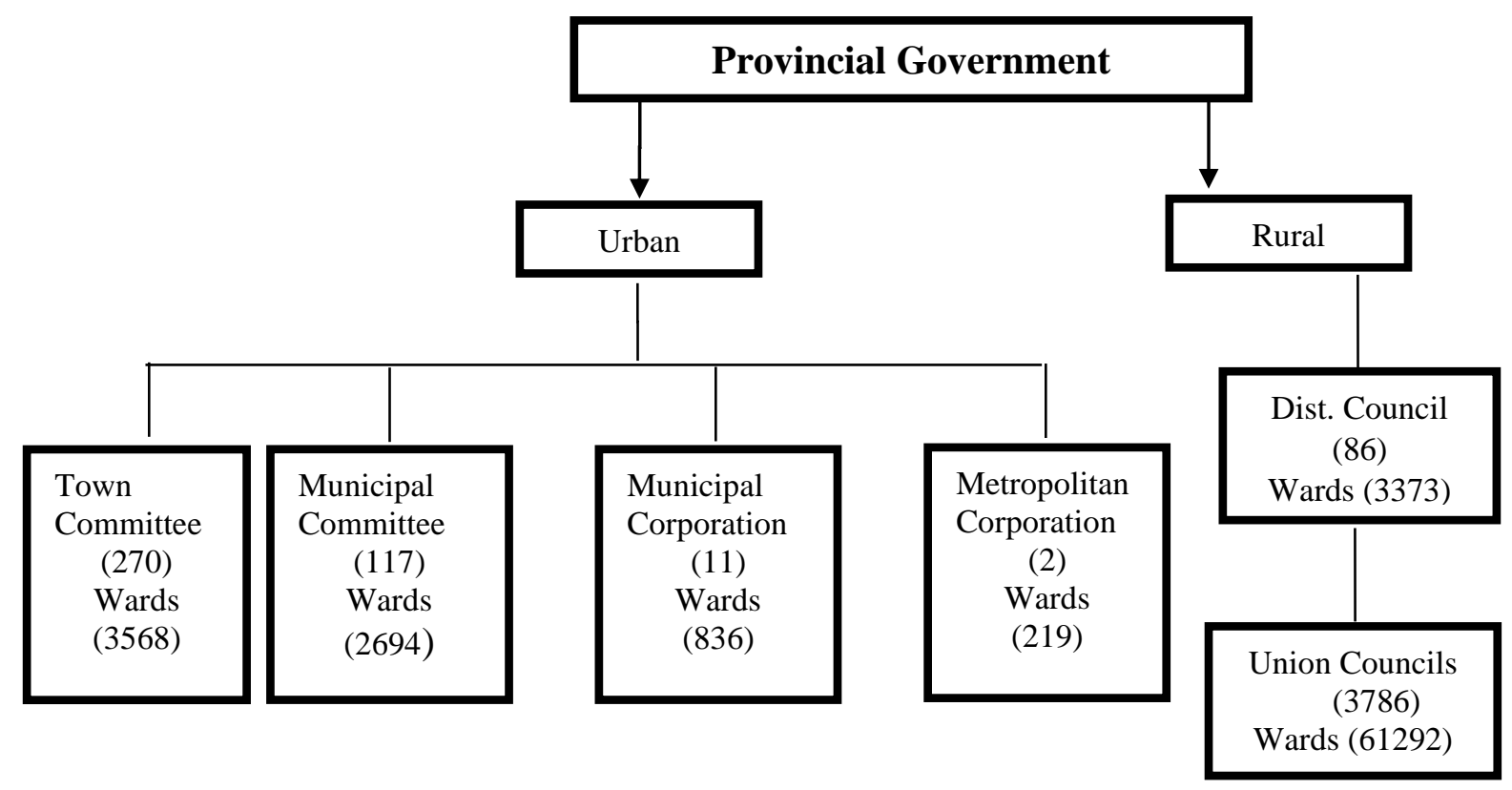

Figure 4: Structure of Local Government during Zia's Regime

Source: The figure has been drawn by the authors.

\subsection{Critical Analysis of Ayub's and Zia's Regimes}

Both policies were based on eliminating the role of political parties from the country's political arena by holding non-party elections. Zia targeted the Bhutto political party, i.e., the Pakistan People's Party. In both regimes, local governments lacked constitutional protection and their creation and maintenance remained at the disposal of the provinces. Even the provincial government retained the power to suppress resolutions and proceedings. Both gave the LG only limited financial powers, so that the LG institutions were dependent on federal and provincial grants and funding.

\section{Devolution of Power Plan for Strengthening Local Government in Musharraf's Regime}

General Musharraf came to power as the fourth military leader. To establish democracy at the grassroots level, General Pervez Musharraf founded the National Reconstruction Bureau (NRB) with the task of initiating the distribution of power. This NRA introduced LGS by introducing the Devolution of Power Plan in 2001, with the aim of transferring power from central government to the grassroots level. For this purpose, an ordinance was incorporated into the constitution as Provincial Indigenous Government Ordinance 2001 (Shah, 2016: 131). It is believed that during the Musharraf era, the transfer of power to the central government was revived in its true spirit, even though the local government was not protected in the constitution.

According to this ordinance, the local government was established based on five ground rules of "d", i.e.

- $\quad$ Devolution of political power

- Decentralization of Administrative Authority

- De-concentration of management functions

- Diffusion of the power authority nexus and

- $\quad$ Distribution of Resources (Sadia, 2012: 6-7).

Figure 5 shows Musharraf's government was keen to build a local government structure to enable the citizens of Pakistan to establish grassroots democracy. Local Government Ordinance / Local Government Ordinance of 2001 put the decentralization plan into effect by giving the people authority and power at the most basic levels and subordinating the bureaucracy to elected representatives. Plan had three tier structures shown below. Provinces and provincial capital were given the status of city district government. 


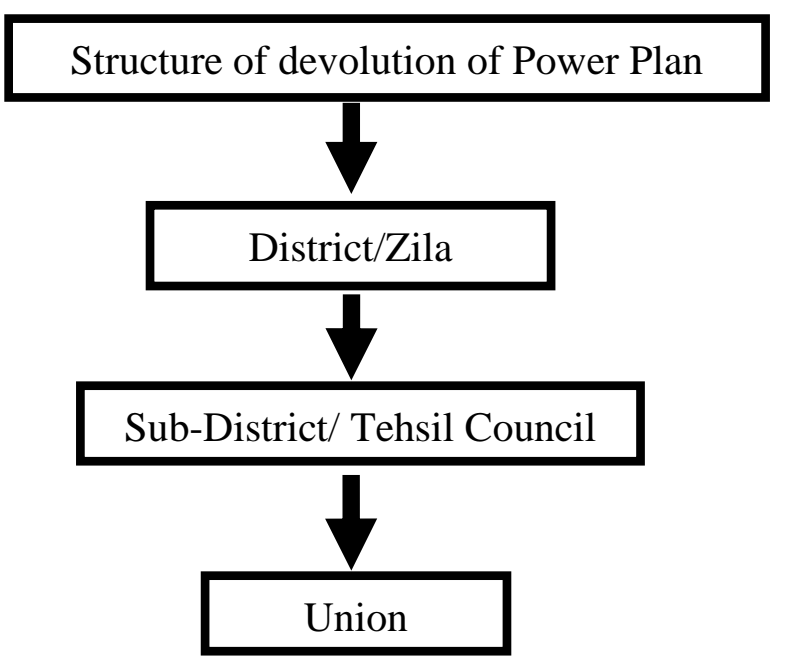

Figure 5 The Structure of Musharraf's Devolution of Power Plan

Source: The figure is made by the authors

- Union Council was the lowest level/tier, which was a body that encompassed both rural and urban areas. It consisted of Nazim and three secretaries and other support staff. Union Nazim was the head of the Union Council administration, whose role includes the provision of municipal services and the proper functioning of the union committee. Union secretaries and their auxiliaries coordinate and support community development programs and processes and have reserve seats for women. The local government was empowered to generate income from its own resources by collecting certain taxes in addition to the provincial tax payments.

- $\quad$ The Tehsil Council was a middle tier/class and had the Tehsil City Administration under the direction of Tehsil Nazim who was entrusted with the administration, finances, and administration of the local government offices. It had reserve seats for women and peasants and was also tasked with rural development and several other issues at the divisional, district, tehsil and lower levels with $1 / 3$ seats for women, minorities and peasants. The council had responsibility to the people and the provincial government for improving governance and service delivery.

Nevertheless, fundamental administrative changes have been prepared in the government departments, such as: B. the departments have been completely abolished. In this way, Musharraf could control bureaucratic power by putting an end to DC's office. Most importantly, local corporations and governments were integrated at the point where the bureaucracy accounted for the elected Nazims, and District Nazim was the actual head of the bureaucracy and was given the control to compel the District Officer's annual performance reports. Musharraf had made radical changes in local government by reserving a third of the seats for women on all local councils. He had set up a National Reconstruction Bureau at the cabinet level to develop a new process of local structure for the provincial government.

\subsection{Criticism}

This power plan proved flawed as the conflict of interest between local government bodies and provincial governments resulted in a lack of property between the government and local bodies. The other problem was the nonpartisan local government system that the Biraderi system put in place for elections, and a lack of control and balances within a system (Hussain, 2008: 4610).

\subsection{Critical Analysis of Zia's Regime and Musharraf's Regime}

Both attempts at decentralization were noteworthy for establishing a local management system. General Zia overthrew the civil government of Zulfiqar Ali Bhutto and the local system of government was introduced by him in 1979 and was called the Local Bodies System. General Musharraf sacked the democratically elected government of Nawaz 
Sharif and the system put in place by Musharraf was called the Devolution of Power. The hidden agenda of the transfer of power, however, was to gain political legitimacy, for which they desperately sought popular support. Women and minorities were represented in both regimes.

From 1988 to 1999, due to the strong political polarization, local affairs were administered and controlled by administrators rather than locally elected representatives. Any military government formed direct military rule after removing a civilian government from power that restricted the government in the name of democracy. In the words of Hayat Sikandar, all decentralization plans work on a similar model to make stronger military dictators at the expense of democracy (Sikandar, 2008: 20). In the past, the process of decentralization was not decentralization, because the local administration in the hands of the provincial government and the centralization forces created worse conditions from time to time. Other factors that make local government vulnerable are sufficient funds and skilled workers with excellent expertise, as well as an efficient structure that has been largely ignored in decentralization plans. A fully competent local government system could be expected if financial constraints were well handled, and financial autonomy was given to address community problems. The performance and functioning of politics and prosperity are entirely based on the availability of local government funding. Now, under the Local Government Act of 2013, the whole concept of decentralization has been revised and some changes have been made, and some features of the Local Government Ordinance of 2001 have been retained.

\subsection{Devolution of Power Plan in the Government of Pakistan People's Party}

After the resignation of President Musharraf, the Pakistani People's Party (PPP) came to power in the 2008 elections. The PPP introduced the 18th amendment that strengthened the autonomy of the provinces. It was now possible for the provinces to formulate their own local system of government. As a result, different provinces chose different structures for their local government. Baluchistan passed its Local Government Act of 2010, while Sindh and Khyber Pakhtunkhwa (KPK) provinces passed their Local Government Acts in 2013.

These provincial Local Government Acts (LGAs) granted local union councils in their affairs related to financial management, control over the provision of services, revenue, tax and police authorities. Although these laws improved service delivery, the provinces had full control over key departments like Karachi Water and Sewerage Board, Sindh Building Control Authority, Lahore Development Authority (LDA) and Solid Waste Management (SWM), etc. The provinces also controlled education and health. In addition, the provincial LGAs subordinated local governments to provincial governments. For example, they allowed provincial prime ministers to dismiss a local government or council chairman and appoint public officials after union leaders were sacked. Unlike the LGAs introduced by the military regimes, the new local government laws ensured party-based local government elections.

The laws enacted, however, had a visible leaning toward provincial governments and were limited in scope to express essential and meaningful powers for the local government system. This reluctance on the part of provincial governments to develop strong local governments during civil rule was since provincial ministers and members of provincial parliaments were able to keep the development funds available to build their networks of political patronage. Such a situation existed because of extended military rules that systematically weakened political parties and democratic political culture that could make a significant difference (Malik, 2019).

\subsection{Critical Analysis of the Government of Pakistan People's Party}

The local system of government under the PPPs government was fraught with more disadvantages than advantages. Although the country experienced the resumption of democracy after nine years, the process of handing over power to the local level was marked by many inconsistencies and political tantrums, such as a lack of approval from the provinces and weak political coordination with lower LG units. Other constraints, such as the activities of opposition parties, civil society, and check-and-balance, have not been 
introduced between the efficiency of local government structures and the level of government. As a result, they are unable to deliver their citizens.

It is true that during the PPPs government the provinces passed their respective local government laws, but the cryptic fact is evident that the provinces were unwilling to delegate their powers to the local union councils. The provinces retained the reins of many powerful departments such as WASA, LDA, and Revenue. The main reason for this practice was to ease the demands of political followers who wanted to maintain control of their political vote bank by not allowing local bodies to properly thrive. It initiated the culture of bribery and corruption. The local corporate system was left to the whims of the members of the national and provincial assemblies. They were bribed by those in the running for seats and posts in the local systems of government. This rampant corruption has seriously damaged the basic idea of the dissolution of power. This trend points to inherent difficulties within Pakistan at the national level in general, and at the provincial level, in building democratic local government systems in the context of non-democratic politics.

\section{Devolution of Power Plan in the Government Pakistan Muslim League (Nawaz Sharif Group)}

It was discussed that provinces have passed their respective LGAs in accordance with the 18th Amendment. Balochistan passed its local government law in 2010, Punjab, Sindh and KPK in 2013. The passage of these laws was an important milestone in Pakistan's history, although lacking enthusiasm and appropriate advice in their formulation was in process. Compared to the Local Government Act of 2001, what is striking about the 2013 laws formulated by the Pakistan Muslim League [Nawaz Sharif Group] (PML-N) government is that none of these laws confer sufficient powers on local governments, but all of them do four provincial governments retained the power to remove or suspend the heads of local governments. The functioning of their funds was administered by the Finance Department and Ministry of Finance of the Provincial Government. All four LG laws emphasize that local elections are held on a party basis. Punjab, Sindh, and Baluchistan would have union councils and district councils in rural areas and union council committees and local councils in urban areas. The KPK's Local Government Act provides for tehsil and village councils in rural areas and neighborhood councils in urban areas (Bhutto, 2016).

Provinces disagree on local governments in the LG Acts of 2013. Punjab has a fiveyear term; Balochistan and Sindh have a four-year term, while KPK has a three-year term. The electoral process also varies between the provinces. In Punjab, the presidents and vicepresidents of the Union Councils are directly elected by direct elections. Sindh provides for indirect elections of the chairpersons and vice-chairpersons of the Union councils from a panel of nine council members, who are elected to the general and reserved seats. In both Punjab and Sindh, the chairpersons of the district councils are elected indirectly through an electoral college that includes all members of the respective council. In the KPK there are direct elections for the members of all seats, either reserved or not, in the village and neighborhood councils. The reserved seats for women, farmers, youth, and minorities are filled through the relationship of the parties based on the seats won (Bhutto, 2016).

\section{Devolution of Power plan in the Government of Pakistan Tehreek-e- Insaf}

In 2018, Pakistan Tehreek-e-Insaf (PTI) was also called the Pakistan Movement for Justice in English and came to power. Imran Khan became Prime Minister of Pakistan as chairman of the PTI. After taking office, he replaced the previous local governments in the provinces controlled by his party and introduced a new one. In Punjab, a new system was codified in the Local Government Act of 2019. It dissolved the existing local governments and set a deadline of April 2020 to hold new elections to form new local governments. It reintroduced the rural-urban separation and advised the establishment of municipal / metropolitan city committees / societies for urban areas and Tehsil councils for rural areas. He decides that the head of each local government should be directly elected by the people. The elected leader will have a cabinet to assist him in performing his duties. It is an extensive list excluding education but excluding health and is included in Lists 3, 4 and 5. The city councils are elected in a closed list according to proportional representation. 
Elections are held on a party basis and each party provides its list of candidates (Malik, 2019).

Depending on the percentage of votes that a party receives, its candidates become councilors of the respective local government. This means that each local government will have a multi-candidate constituency. This new system also establishes panchayats and neighborhood councils for rural and urban areas. These are intended as basic forums at village and community level. While these forums have no inherent powers, they can inherit powers from local governments. The new law maintains the supervisory role of provincial governments by requiring local governments to obey provincial decisions. This particularly applies to financial matters. The provincial governments can stop any decisions they consider to be detrimental to the public interest. The law also provides for the establishment of a new institution. This inspectorate reviews the performance of each local government in detail once a year and can request as many inspections as it deems necessary. These inspections are carried out in addition to the usual audits (Saleem, 2008).

The Pakistani Tehreek-i-Insaf (PTI) will introduce a two-tier local government system in Punjab and two other provinces with all-powerful mayors, huge development funds and control over many departments. Punjab has the abolition of Tehsil. This system has proposed council level in the proposed reorganization. In this case, there will only be district and union councils. Khyber Pakhtunkhwa's suggestion is to keep only Tehsil and village councils. The office of mayor is modeled on London or Washington; and mayor is a powerful official of LGS. Municipalities receive a third of the development budget, mayors are elected directly. The mayors would be elected directly with the entire district as an electoral college, not after the house. The idea is that citizens can elect a mayor of their choice. The separation between town and tehsil of a district, reintroduced by the previous Shahbaz Sharif government, remains in place. Local elections are held on a party basis as the decision of the Lahore Supreme Court in the Imrana Tiwana case prohibits non-party elections. Non-party elections are not even allowed under Article 140 of the Constitution (Hanif, 2018). On the other hand, The PPP's government in Sindh recently amended the 2013 Local Government Act to transfer numerous powers from local governments to the provincial government to strengthen their political position at the provincial level in the 2023 general election, according to the political analysts (Abid, 2022). This act of the ruling PPP provincial government has united all political parties and lobbyists who were previously politically isolated and now condemn and label this act of the PPP as unconstitutional.

The PTI government's actions for LG elections started with a bang in the provinces of Punjab and Khyber Pakhtunkhwa. PTI conducted the first phase of the LG elections in 17 districts of Khyber Pakhtunkhwa on December 19, 2021, although the implementation was delayed by more than a year by its provincial government. In contrast to the changed voting behavior at the polls in the 2018 parliamentary elections, the PTI government seems to lose the LG elections in the KPK quite unexpectedly, because Maulana Fazlur Rehman's JUI-F (officially called Jamiat-i-Ulema Islam by some party leaders) rose through the win of more seats to become the largest party in the province as compared to the former. The PTI must be appreciated for the open acceptance of the election results announced so far. It, despite this severe election setback in the power base, has started the institutionalization of LC electoral process to search for pluralistic representatives. Linked to it, this was an effort to bring order into the internal affairs of the party instead of repeating its past political behavior of finger-pointing and allegations of rigging, which is the case in Pakistan's political culture (Mehboob, 2021). ${ }^{2}$ The same effort was launched in Punjab in late 2021; however, the LG elections were not held during the four years of the PTI provincial government. On 2 December 2021, PTI and its ally Pakistan Muslim League-Quaid (PMLQ) announced mutually agreed draft about the new set-up of Punjab Local Government System (PTI, PML-Q agree on new LGs set-up in Punjab, 2021). Punjab Punjab Governor Chaudhry Mohammad Sarwar passed the Punjab Local Government Act 2021 to pave the way for local party-based provincial elections. The provincial cabinet has already given its approval and the decree passing its de facto law has been signed by the governor (Governor signs LG Act 2021, paving way for polls, 2021). 


\subsection{Salient Characteristics}

Its Salient features are as follows.

1. Punjab's formation of the new local governments (LGs) will include 11 metropolitan corporations including Gujrat and Sialkot and all metropolitans will be having nine divisional headquarters. Neighborhood councils are 2,171 and village councils are 3,433. "There will be 11 metropolitan corporations and 10 district councils in the rural area of the metropolitan districts other than Lahore. There will be 25 district councils in the non-metropolitan districts" (Abid, 2022). ${ }^{3}$

2. Other 25 small districts of the province would have district councils and sub-division will likely be tehsil councils, municipal councils and municipal committees, and village/town committees." Village councils will be at the lowest level of local government system.

3. The Metropolitan Corporation is headed by the Lord Mayor, while the District Councils are headed by the District Mayor. See Figure 6.

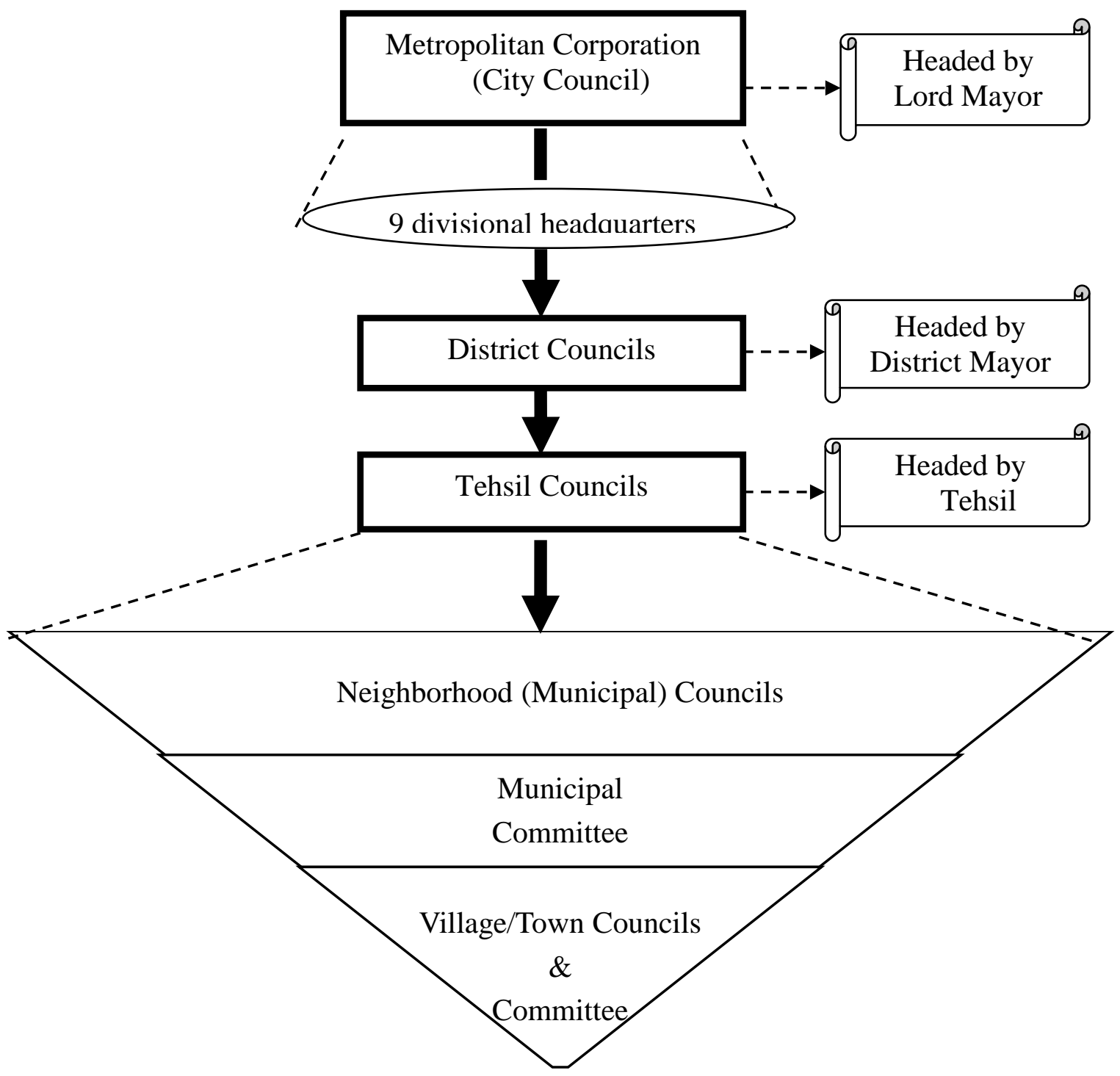

Figure 6 Structure of Proposed Local Government System under PTI's Regime Source: the figure is made by the authors.

4. Women, minorities, peasants, labor, and youth will contest the LG elections for the office of mayor and deputy mayor by panels in direct vote(Abid, 2022).

5. Five departments of education, health, population, social welfare, and sports, which were previously administered by the provincial government, now will be in the domain of the local government. On the other hand, metropolitan corporations will control the

\footnotetext{
${ }^{3}$ https://www.thenews.com.pk/tns/detail/921405-localising-governance
} 
other departments such as Development authorities, parks and horticulture, parking companies, TEPAs, waste management companies and water and sanitation agencies(Abid, 2022).

6. According to the Supreme Court order, the LG elections will be party based. for all upper echelons, internal voting is direct and party-based, 60 percent based on heads of panel and deputy, and councilors on reserved seats, 40 percent based on closed proportional representation (general councilors) on a voting slip (called ballet paper) (Abid, 2022).

7. A head of cabinet of a local government, except for the neighborhood council and the village council, will appoint and set up councilors and technocrats. Technocrat members must demonstrate a degree that requires sixteen years of education and five years of work experience (Abid, 2022).

8. Neighborhood and village councils will receive 30 percent of development fund directly from the provincial government (Abid, 2022).

9. Five-member councilors of community/panchayat (with no fewer than two female members) are nominated under each National Council and Village Council (Abid, 2022).

10. The district councils have set a quota for the disabled (Abid, 2022).

\subsection{Critical Analysis of the Local Government Acts During the Periods of PML-N and PTI}

Although the 2013 law gave more powers to local government, i.e., the decentralization of education and health, these areas remained under the control of the province. However, the local provincial government law (PGLA) 2019 placed the administration of the schools directly under the local government. The problem of overlapping powers has also been resolved, with citizen agencies such as the Water and Sanitation Authority (WASA) now falling under the control of the local government. The PGLA 2019 is more tangible in its representative character than its predecessor law. As the heads of local government are directly elected, the new system has empowered it to eliminate previous abuse of influence by unelected members.

It is undoubtedly clear that the system put in place by the PTI is far better than the PML-NS Act of 2013. The PML-NS Act allowed party-based elections, but most city councils indirectly held high offices. The government has also made many legislative changes over time. It later introduced the provision of appointing technocrat members who can then become mayors. It weakens the local system of government. The PGLA 2013 also did not provide for any sensible decentralization of finances from the provincial to the local level. Local governments had little money and were dependent on the provincial government and the bureaucracy. In comparison, PTI's local government laws seem to transfer real tax or administrative matters to the local level. They also aim to encourage people to participate directly in local politics. However, these laws are not without problems. Their ambitious scope raises questions about their implementation and the capacities of the local governments they have created (Ali, 2019).

As with the 2021 local government system, powers of over 20 departments will be transferred to metropolitan corporations' governments, including tourism, transport, and sport. For the first time in history, the administration of these three departments at the district level is entrusted to the district governments, measures and collection of local taxes and bills. Currently, an overwhelming majority of mayors and councilors belonged to the PML-N, but the law under which they were elected - Local Government Act 2013 - gave them no powers. Even the local functions in large cities like Lahore have been taken over by companies established by the former Punjab government. Officials say the law contains no provision allowing councils to be suspended or dismissed; they will not cease to exist until the PTI government introduces new law. Sources said Punjab has offered to abolish the Tehsil councils' middle class, given the problems faced by the Musharraf-era local government system. The lack of control and balance led mainly to corruption and mismanagement in these councils, which formed the backbone of the system (Hanif, 2018).

\subsection{Criticism and Imminent Challenges in front of the PTI's government}

The indifferent and half-finished restoration of local government institutions in Punjab was carried out by a ruling by the Supreme Court of Pakistan. Under this 
arrangement, Pakistani rupees 26.63 billion have been allocated in the provincial budget for the restoration of local government in Punjab. Most local government officials do not have offices to work from. This suggests that the local system of government is being ignored by another elected government. In the run-up to the 2013 and 2018 elections, Prime Minister Imran Khan had promised in many speeches that the members of the national and provincial parliaments would receive no development money other than that their constitutional role would be limited to legislation. He believes that local governments in Pakistan should be strengthened and that local governments should receive development funds in accordance with their mandate. Instead, the PTI government in Punjab suspended the existing local system of government. The last elections in Punjab took place in phases in 2015 and 2016. Local governments were formed on January 1, 2017, for a five-year term ending December 31, 2021. The Municipal Law 2013 was dissolved on May 3, 2019. In the 2019 PLGA, the term of office of local governments was reduced to four years (Bukhari, 2021).

However, some PML-N leaders petitioned the Supreme Court to oversee the restoration of local government in Punjab for them as the Supreme Court (SC) threemember bank announced a ruling on their reinstatement in March 2021. But this dream has yet not come true because of political and economic reasons. (1) When the local government officials arrived at their offices, the administrator refused to hand over the indictment by order. We filed a disregard motion from the court, which also worked, and the government assured the court that local governments would be reinstated, says Col Mubashir (retired), the mayor of Lahore. Sohail Butt, who was elected chairman of UC 213 in Lahore in 2016, expressed his views that 'we as unelected people work on the very small scale, using our own limited available resources only for the PTI, which has given the authority as administrators and secretaries at the district level to take care of the people. He adds more that the local government elected officials told them there was no space for their offices. We spent out of pocket because people voted for us and therefore expect us (Bukhari, 2021).

The other challenges that may stand in the way of local government's elections (LGE) are(Abid, 2022): (1) As the current term of local government in Punjab has expired, the powers of local government will be delegated to the Chief Minister and his affairs will be settled by nominated administrators and Bureaucracy that ensures full control of the provincial government over the affairs of the LGs in the absence of fixed local legislation and elected representatives of this system (2) The local government law has not yet been enacted. (3) The use of electronic voting machines in future local elections can lead to further delays. (4) There are no such scientific qualification restrictions for the office of mayor and deputy mayor or for members of the parliament. (5) As economist Qais Aslam says, the chances of tremendous corruption in budgetary allocations do not depend on the small or large amount allocated. What is important is what, where and how you spend. However, the transparent spending of almost Pakistani rupees 26 billion on the LGS is dubious. Political concerns of the opposition are that the allocation is likely to be distributed among the PTI's own and allied MPAs and workers to strengthen the party at the provincial level. On the other hand, Punjab government spokesman Musarrat Jamshed Cheema told TNS: The PTI believes in transparency and merit. The budget allocation will be transparent(Abid, 2022).

The real side of this picture, however, is that the PTI's internal fear of defeat and the feeling of insecurity of being unpopular locally prevent itself from holding LGEs. They passed the Punjab Local Government Act 2019 and suspended the elected bodies in 2019. The defeat is that the PTI that if the elections were held immediately, the PML-N would remove most of the seats from the Punjab because of poor performance by Prime Minister Usman Buzdar, who created a strong sense of insecurity in the unpopular province. As a result, the PTI fails to deliver on its promises to strengthen local governments and decentralize power. Another challenge looms on December 31, 2021, when the current bodies end their terms and holding new elections will be a major challenge. If the PTI immediately holds the polls and loses heavily, the 2023 general election may be lost as the trends and dynamics of the LCS of Pakistan's political culture predict the formation of the next government. To change this dynamic, the PTI urgently needs to take some immediate political action at the Punjab level, such as the appointment of a proactive chief minister to 
increase its popularity in Punjab, who can run the province with political wit and active administrative skills. This can only lead to the success of the PTIs government formation at the federal level(Abid, 2022).

\section{Conclusion}

In general, the local government system appears to be more accessible and responsive to local needs, as they are empowered to elect the officials, collect taxes, and perform duties for their specific small areas. Therefore, local government developed from the local people according to their own desires and experiences and always remained supportive in relation to the development process at the lower level. Because it brings efficiency to the administration; Representatives from the local areas understand the problems and solve them better. By delegating the work to local bodies, the workload of the provincial government is reduced, and the local bodies are given subsequent administrative and financial autonomy. Local government is the third tier of government in Pakistan after national and provincial governments. Since independence, the distribution of power has been the focus of attention, and many experiments have been carried out to eliminate people's dissatisfaction, but they have failed.

But throughout the history, the trend of devolution of power in Pakistan has remained under the influence of vested interests of ruling elites. Either, under the military regime, the ruling powers used the bureaucratic control through the BDS, and no constitution protection is given to the elected local bodies and financially restrained to the local governments. Such things have been embedded in the LGs to ensure the political legitimacy of military rule. During the military era, the core purpose of transfer of powerto authorize people at the grass root level- had not achieved with the purpose of national integration; in fact, the system remained a part of political culture. Or the civilian governments have been rendered the local governments with the limited autonomy on many imperative matters such as financial management, revenue, and tax collection to provincial government. These provincial governments always hesitant to establish a strong LGS and use development funds for their own political patronage, which is the main reason that the LGS could not build up its roots within Pakistan's political system.

\subsection{Findings}

Local government is the third tier of government in Pakistan after national and provincial governments. Since independence, the distribution of power has been the focus of attention, and many experiments have been carried out to eliminate people's dissatisfaction, but they have failed. The results of the study shed light on the facts that the lack of the weaker local government system in the South Asian region in general, and in Pakistan in particular, is due to several reasons. (1) the colonial legacy of an enduring controlled political mindset in the form of a strong bureaucratic system in which power could not easily be decentralized; (2) Half-hearted and reluctant behavior and approach by bureaucrats to delegate their powers to and work in synergy with local government officials; (3) Frequent military coups and vested interests of political parties to derail the then democratic and civil government; (4) a lack of true political will to develop a welfare state in Pakistan; (5) incompetency of political leadership pushes the country towards the culture of poor governance and weak institutionalization.

Regardless of the results of the study and the challenges facing by Imran Khan's government, his administration will be the first elected government whose real political intent and effort is to pave the way for a resilient local system of government in Pakistan in future, provided, he stands firm on his promise distribute the powers that are essential for a welfare state to the local level and not to give up in the face of failures, challenges and setbacks.

\subsection{Recommendations}

Currently, the pattern of local government existing in Pakistan is characterized by decentralization but has not proved to be successful in these regards to eradicate certain weaknesses of local institutions in Pakistan and improve their working efficiency certain recommendations must be viewed. These are as follow. 
- Despite tremendous progress in recent years, the local elected bodies are not well established. A comprehensive and define framework of local government structure is needed with which the local bodies can function independently and work smoothly without interference.

- Human resources capacity should be developed for service delivery and ensure viable progress. And in the local system administration, honest, knowledgeable, and professional persons should be appointed.

- In decision making process, the representational seats of women should be increased in order to give them equitable participation.

- To achieve administrative effectiveness, a legal framework should be maintained, and close cooperation should be retained between the government and the local organization.

- With due economic assistance and independence in policymaking, the economic efficiency of local government can be achieved. And the local bodies must be given sufficient authority and power to fulfill their responsibility and performed their duties.

- To ensure accountability, right to impeach the District and Tehsil Chairmen should be granted to the councilors and to recruit staff on merit. Local Government Service Commission should be formed that work in coordination with the chairman of the District Council.

Currently, the pattern of local government in Pakistan is characterized by decentralization, but has not proven successful in this regard, to remedy certain weaknesses of local institutions in Pakistan and improve their work efficiency, some recommendations need to be considered. These are as follows: Despite tremendous progress in recent years, the local elected bodies are not well established. A comprehensive and well-defined framework is required for the local government structure, within which local bodies can function independently and smoothly without interference. Human resource capacities should be developed for service delivery and sustainable progress ensured. And honest, knowledgeable, and professional people should be appointed to local systems administration. In decision-making processes, women's representative seats should be increased to allow them to participate fairly. Devolution of power at the grass root level leads to more active interaction and participation of the masses in all the tiers of the government that will help in restoration of real democracy in the government. Along with, enabling the local government to raise funds and manage their affairs from their own resources, effective lower judiciary is an important part of system of devolution. To provide cheap and immediate justice, it is the need to create new local judicial institutions and strengthen the existing one.

For the administration to be effective, a legal framework should be maintained, and close cooperation should be maintained between the government and the local organization. With the appropriate economic aid and independence in policymaking, the economic efficiency of local government can be achieved. And local authorities must be given sufficient authority and authority to discharge their responsibilities and perform their functions. To ensure accountability, councilors should be given the right to prosecute the district and Tehsil chairpersons and hire staff on a merit. A local government service commission should be established to work in coordination with the chairman of the district council.

Last but not the least, a proposal for a federal framework is presented to ensure success in implementing the local government tier. The argument put forward is that while this matter falls within the domain of the province, the supervisory mechanism should be put in place by the federal government, based on transparent evaluation and ongoing monitoring of local government systems. The counterargument, however, is that this can lead to institutional clashes in future between provincial and local governments when one party takes power in a local government and a competitor party in the provincial government. Another proposal is for parliamentary and local elections to be held at the same time or shortly after the general election, no more than 120 days later, but with the same term of office established for all tiers of government (Abid, 2022). 


\section{References}

Abid, S. (2022, January 2). Localising governance: Special Report. Retrieved from The News: https://www.thenews.com.pk/tns/detail/921405-localising-governance

Ahmed, M. (1970). Government and Politics in Pakistan . Karachi: Royal Book Company.

Ali, S. A. (2019, 07 05). The good, the bad and the Ugly in Punjab's new Local govt System. Retrieved 05 28, 2020, from dawn: https://herald.dawn.com/news/1398912

Bhutto, P. (2016, 04 12). Local Government System in Pakistan. Retrieved 05 28, 2020, from slideshare: https://www.slideshare.net/pariibhutto/local-government-systemin-pakistan

Bukhari, M. (2021, June 27). Local governments in 2021-22. Retrieved from The News: Special Report: https://www.thenews.com.pk/tns/detail/854952-local-governmentsin-2021-22

Buneri, S. H. (2018). A Cursory Glance on structure og Local Government system in Pakistan . Lahore: The Frontier Post.

Chiragh, M. A. (2004). Pakistan: History, Democray, Politics and Constitution . Lahore: Sang-e-Meel Publications .

D.E.Ashford. (1967). National Development and Local Reforms: Political participation in Moroccow Tunisia and Pakistan. Princeton: Princeton University Press.

Governor signs LG Act 2021, paving way for polls. (2021, December 12). Retrieved from The Express Tribune: https://tribune.com.pk/story/2333568/governor-signs-lg-act2021-paving-way-for-polls

Hanif, I. (2018, September 9). PTI plans two-tier LG system sans tehsil councils in Punjab. Retrieved from Dawn: https://www.dawn.com/news/1431777

Hussain, Z. (2008). Devolution, Accountability and Service Delivery: Some Insights from Pakistan. D.C. Washington: World Bank .

Imran, M. (2015, November 10). The Concept Of Good Governance In Modern World And Governance By Caliphs Of Islam - Part II. Retrieved December 2, 2021, from Courting the Law: https://courtingthelaw.com/2015/11/10/commentary/theconcept-of-good-governance-in-modern-world-and-governance-by-caliphs-of-islampart-ii/

Khan, H. (2009). Constitutional and Political History of Pakistan. Karachi: Oxford University Press.

Larson, A. M. (2002). Democratic Decentralization in the Forestry Sector: Lessons Learned from Africa, asian and Latin America. Interlaken, Switzerlan: Center of International Foresty Research.

Malik, M. N. (2019, 08 05). The History of Local Governance in Pakistan: What Lessons to learn? Retrieved 05 28, 2020, from researchgate: https://www.researchgate.net/publication/335319273_The_History_of_Local_Gover nance_in_Pakistan_What_Lessons_to_Learn

Mehboob, A. B. (2021, December 30). Local government's return. Retrieved from Dawn: https://www.dawn.com/news/1666622

Mussarat, D. R. (2011). Decentralization Reforms in Pakistan. Journal of public Administration and Governance, 123-133.

Pakistan, G. o. (1973). The Constitution Islamic Republic of Pkistan . Islamabad: Government of Pakistan Press.

PTI, PML-Q agree on new LGs set-up in Punjab. (2021, December 3). Retrieved December 10 , 2021, from The News : https://www.thenews.com.pk/print/913655-pti-pml-qagree-on-new-lgs-set-up-in-punjab

Rabbani, I. (2006). Constitutional and political development 1977-1985. Lahore: Carvan Book House.

Sadia, S. (2012). Political and Administrative Structure of Local Bodies in Pakistan:A Case Study of City District Government Faisalabad. Barkely Journal of Social Science, 6-7.

Saleem, A. (2008, 10 06). Local Govt Reforms in Pakistan. Retrieved 05 28, 2020, from Nation: https://nation.com.pk/06-Oct-2008/local-govt-reforms-in-pakistan

Sayed, K. (2014). The Politicall system of Pakistan. Lahore : Peace Publications.

Shah, N. H. (2016). Comparison of Local government Concept of Ayub and Musharaf Devolution Plan . Gomal University Journal of Research, 129-141.

Siddiqui, K. (1992). Local Government in South Asia: A Comparative Study. Dhaka: Dhaka University Press. 
Sikandar, A. H. (2008). Decentralizatuon without democracy in Pakistan. Switzerland: Institute of Federalism.

Tate, C. N. (2014, January 23). Constitutional Law - Unitary and Federal System: the Distinction between Unitary and Federal States. Retrieved January 25, 2014, from Encyclopedia

Britannica: http://www.britannica.com/EBchecked/topic/134322/constitutionallaw/22074/Unitary-and-federal-systems\# ref909511

Ziring, C. I. (1977). An Introduction to Asian Politics . USA: Prentice Hall. 